\title{
EDUKASI KESEHATAN DALAM UPAYA MENJAMIN KERAHASIAAN MEDIS PASIEN PADA FASILITAS PELAYANAN KESEHATAN
}

\author{
${ }^{1}$ Arief Setiyoargo, ${ }^{2}$ Cecilia Widijati Imam, ${ }^{3}$ Richard One Maxelly \\ ${ }^{123)}$ Prodi Sarjana Terapan Manajemen Informasi Kesehatan STIKes Panti Waluya, Malang, \\ Indonesia \\ Corresponding author: setiyoargoarief@gmail.com
}

\section{Informasi Artikel}

Terima : 31/03/2021

Revisi : 22/05/2021

Disetujui : 12/08/2021

Kata Kunci:

Informed Consent,

Kerahasiaan Medis,

Pasien

\begin{abstract}
ABSTRAK
Kegiatan Pengabdian Masyarakat "Edukasi Kesehatan Dalam Upaya Menjamin Kerahasiaan Medis Pasien Pada Fasilitas Pelayanan Kesehatan" diawali dengan pengkajian awal terhadap keadaan lapangan saat ini pada fasilitas pelayanan kesehatan melalui tenaga kesehatan/kader kesehatan dan warga. Pengkajian awal didapati masih kurangnya edukasi mengenai privasi dan kerahasiaan medis pasien terutama di saat pandemi Covid 19 saat ini fokus pelayanan kesehatan masih terpusat pada protokoler kesehatan atau physical distancing. Hasil survey menunjukkan bahwa masih kurangnya pengetahuan tenaga kesehatan/kader kesehatan dalam menjaga kerahasiaan medis, pengetahuan terkait hak dan kewajiban antara dokter dan pasien serta prosedur pelaksanaan kerahasiaan medis di fasilitas kesehatan. Kegiatan dilanjutkan dengan menyusun perencanaan dan jadwal kegiatan serta perlengkapan yang diperlukan. Bentuk kegiatan dikermas dalam bentuk materi dan video tentang pentingnya menjaga kerahasiaan medis dalam pelayanan kesehatan, pemahaman tentang hak dan kewajiban antara dokter dan pasien serta prosedur pelaksanaan kerahasiaan medis melalui pelaksanaan informed consent. Kegiatan diakhiri dengan evaluasi di setiap kegiatannya. Hasil dari kegiatan pengabdian kepada masyarakat terdapat sebanyak $61,5 \%$ pemahaman warga dalam katergori baik, cukup sebanyak $23 \%$ dan kurang sebanyak 15,5\%. Kegiatan berjalan dengan baik dan perlu adanya monitoring lebih lanjut.
\end{abstract}

PENDAHULUAN

Keterbukaan informasi saat ini menjadi kebutuhan bagi setiap anggota masyarakat yang wajib dipenuhi oleh pemerintah. Pemanfaatan teknologi informasi seperti media massa dan perangkat informasi lainnya telah mengubah perilaku masyarakat secara global bahwa segala informasi dapat diakses menjadi tanpa batas. Kondisi ini memberikan kontribusi positif bagi peningkatan kesejahteraan, kemajuan 
dan peradaban manusia, namun di sisi lain akan memunculkan permasalahan baru dalam kaitannya dengan kebutuhan peraturan terkait perlindungan hukum.

Penyediaan informasi kesehatan oleh penyelenggara pelayanan kesehatan merupakan sebuah kewajiban yang ditetapkan oleh undang-undang dan harus dipenuhi. Perkembangan teknologi yang mengarah kepada sistem informasi kesehatan akan meningkatkan akses, mutu, dokumentasi dan fungsi pelayanan kesehatan lainnya. Namun, di sisi lain hal ini akan menimbulkan masalah hukum jika informasi tersebut menyangkut kondisi kesehatan seseorang (pasien). Informasi yang menyangkut data diri pasien merupakan sebuah rahasia medis (rahasia pasien/rahasia kedokteran). Rahasia medis pasien merupakan hak pasien yang harus dihormati. Mengingat pentingnya rahasia medis pasien tersebut, maka diaturlah beberapa peraturan perundang-undangan di bidang kesehatan terutama dalam (DPR RI, 2004) yang menyebutkan bahwa setiap dokter atau dokter gigi wajib menyimpan rahasia kedokteran.

Peranan fasilitas pelayanan kesehatan terutama rumah sakit sangat penting dalam menunjang pelayanan kesehatan terutamanya pelayanan medis. Pelayanan kesehatan merupakan hal penting yang harus dijaga dan ditingkatnya kualitasnya sesuai standar pelayanan yang berlaku agar masyarakat sebagai konsumen dapat merasakan pelayanan kesehatan yang diberikan. Syarat terjadinya sebuah pelayanan kesehatan yang baik adalah adanya rasa saling percaya dan memahami hak dan kewajiban masing-masing antara pasien dengan tenaga medis terutama dokter. Pasien mempunyai kewajiban untuk menceritakan segala hal-hal yang terkait dengan penyakitnya karena pasien mempercayai pengobatan atau perawatan yang dilakukan oleh tenaga medis/dokter. Dokter juga mempunyai kewajiban untuk merahasiakan hal-hal yang diketahuinya karena jabatan atau pekerjaanya yang berpijak pada norma susila dan pada hakikatnya hal tersebut merupakan kewajiban moral. Seorang pasien mempunyai hak asasi untuk menentukan siapa saja yang boleh mengetahui tentang kondisi dirinya.

Suatu profesi kesehatan merupakan suatu profesi kepercayaan dan dianggap sebagai profesi yang mulia, karena pekerjaan yang dilakukan membutuhkan suatu keahlian dan beresiko terhadap nyawa manusia. Tidak hanya pada tindakan medis yang dilakukan tetapi juga pada tindakantindakan yang berlandaskan hukum dan 
moral. Seringkali dalam kenyataannya, kewajiban untuk merahasiakan catatan medis seseorang bertabrakan dengan kepentingan umum. Seorang tenaga kesehatan sangat perlu memperhatikan batasan-batasan dalam merahasiakan dan membuka rahasia medis kepada umum.

Perkembangan jumlah penduduk pada suatu kawasan membawa perubahan besar pada kebutuhan dasar manusia yaitu kebutuhan akan sandang, pangan dan papan serta fasilitas penunjangnya. Kebutuhan dasar tersebut terus meningkat secara alamiah seiring kompleksitasnya kebutuhan hidup bermasyarakat seperti aktivitas sosial, aktivitas ekonomi dan aktivitas pelayanan umum. Dari kondisi tersebut menuntut adanya pembangunan sarana dan prasarana pada suatu kawasan guna menjaga kelangsungan hidup masyarakat terutamanya di daerah perkotaan. Salah satunya yaitu kebutuhan akan sarana atau fasilitas pelayanan kesehatan sebagai bentuk kebutuhan dasar manusia dalam mempertahankan keberlangsungan hidupnya. Fasilitas pelayanan kesehatan memberikan banyak manfaat diantaranya memberikan pelayanan promotif, preventif, kuratif dan rehabilitatif serta edukasi kesehatan kepada masyarakat.
Pada masa pandemi Covid 19 saat ini yang sedang melanda Indonesia dan dunia juga turut memberikan dampak di berbagai daerah di tanah air. Covid 19 bukan hanya merupakan suatu wabah biasa, melainkan sebuah pandemi sehingga WHO (World Health Organization) sebagai organisasi kesehatan dunia memberlakukan physical distancing untuk menekan penyebaran virus tersebut. Adanya kebijakan dari pemerintah utnuk memberlakukan physical distancing tersebut juga turut memberikan dampak bagi masyarakat, salah satunya yaitu pelayanan di fasilitas kesehatan. Saat ini pelayanan kesehatan hampir seluruhnya berfokus pada pengobatan dan perawatan dari pasien Covid 19 serta pemberlakuan physical distancing, tentunya hal ini sangat berpengaruh pada pemenuhan fungsi fasilitas pelayanan kesehatan dalam memberikan edukasi kesehatan. Edukasi kesehatan dirasa sangat penting terkait kegiatan pelayanan kesehatan yang diberikan sehingga dapat diwujudkan rasa saling percaya antara tenaga kesehatan dan pasien terutama mengenai pemahaman hak dan kewajiban masing-masing dalam pelayanan kesehatan terutama dalam menjaga privasi dan kerahasiaan medis pasien. 
Sehubungan

dengan

permasalahan tersebut, pihak STIKes

Panti Waluya Malang melaksanakan kegiatan pengabdian kepada masyarakat dalam memberikan pembinaan, pendampingan dan konsultasi dalam pentingnya menjaga kerahasiaan medis dengan pembinaan terkait pemahaman hak dan kewajiban antara dokter dan pasien serta prosedur pelaksanaan kerahasiaan medis dengan informed consent sehingga dapat digunakan untuk meningkatkan pelayanan kesehatan masyarakat terutama mengenai privasi dan kerahasiaan medis pasien secara berkelanjutan pada fasilitas pelayanan kesehatan.

\section{METODE KEGIATAN}

Pelaksanaan kegiatan pengabdian masyarakat ini berlangsung selama 3 kali pertemuan kepada warga RT.4 RW.4 Kel. Jati Kec. Mayangan Kota Probolinggo.

Metode pelaksanaan yang diterapkan untuk mencapai tujuan dari program kemitraan ini adalah dimulai dari tahap persiapan dengan mengurus birokrasi dan permohonan ijin kepada pihak terkait, pertemuan dengan tokoh masyarakat dan petugas kesehatan, mengobservasi prosedur pelayanan kesehatan antara tenaga kesehatan dan pasien.

Tahap pelaksanaan dilakukan dengan memberikan sosialisasi bagi tenaga/kader kesehatan dan masyarakat secara daring mengingat dalam kondisi pandemi Covid 19, mengenai pentingnya menjaga kerahasiaan medis pasien, memberikan penyuluhan tentang pemahaman mengenai hak dan kewajiban antara dokter/tenaga kesehatan dan pasien, dan selanjutnya yaitu memberikan contoh dalam prosedur privasi dan kerahasiaan medis pasien dalam bentuk informed consent pada fasilitas pelayanan kesehatan.

Tahap evaluasi dilakukan untuk menilai tingkat pemahaman kader terkait pentingnya menjaga kerahasiaan medis pasien, pemahaman mengenai hak dan kewajiban antara dokter/tenaga kesehatan dan pasien dan memberikan contoh dalam prosedur privasi dan kerahasiaan medis pasien dalam bentuk informed consent pada fasilitas pelayanan kesehatan. Evaluasi dilakukan melalui tanya jawab langsung pada awal penyuluhan dan post test dilakukan pada akhir tahap penyuluhan.

\section{HASIL DAN PEMBAHASAN}

HASIL 
Karakteristik warga RT.4 RW.4 Kel. Jati

Kec. Mayangan Kota Probolinggo adalah bapak-bapak dan ibu-ibu yang aktif pada berbagai kegiatan kesehatan dan kemasyarakatan yang seluruhnya berjumlah 26 orang. Adapun warga yang memiliki pekerjaan sebagai tenaga kesehatan sebanyak 2 orang.

Tabel 1 Distribusi Frekuensi peserta PKM Berdasarkan Jenis Kelamin

\begin{tabular}{cccc}
\hline No. & $\begin{array}{c}\text { Jenis } \\
\text { Kelamin }\end{array}$ & Frek & Prosentase \\
\hline 1. & Laki-laki & 13 & $50 \%$ \\
2. & Perempuan & 13 & $50 \%$ \\
\hline \multicolumn{2}{l}{ Total } & 26 & $100 \%$ \\
\hline
\end{tabular}

Distribusi Peserta berdasarkan profesi dapat dilihat pada tabel 2 berikut:

Tabel 2 Distribusi Frekuensi peserta PKM Berdasarkan Profesi

\begin{tabular}{cccc}
\hline No. & Profesi & Frek & Prosentase \\
\hline 1. & $\begin{array}{c}\text { Tenaga } \\
\text { Kesehatan }\end{array}$ & 2 & $7,7 \%$ \\
2. & Pedagang & 11 & $42,4 \%$ \\
3 & $\begin{array}{c}\text { Pekerja } \\
\text { Kantor } \\
\text { Ibu } \\
\text { Rumah } \\
\text { Tangga }\end{array}$ & 6 & $23 \%$ \\
\hline & Total & 26 & $100 \%$ \\
\hline
\end{tabular}

Hasil kegiatan pada tanggal 31 Agustus 2020 terkait penyampaian materi tentang pentingnya menjaga kerahasiaan medis dengan metode ceramah dan tanya jawab berhasil dilaksanakan dengan indikator peserta mampu memahami materi yang disampaikan secara umum. Selanjutnya, hasil kegiatan pada tanggal 4-7 September 2020 terkait pemahaman hak dan kewajiban antara dokter dengan pasien serta prosedur pelaksanaan privasi dan kerahasiaan medis melalui metode pemberian materi dan video pembelajaran serta tanya jawab secara online juga berhasil dilaksanakan dengan indikator peserta mampu mengerti materi tentang prosedur pelaksanaan privasi dan kerahasiaan medis serta penggunaan informed consent.

Hasil tanya jawab online:

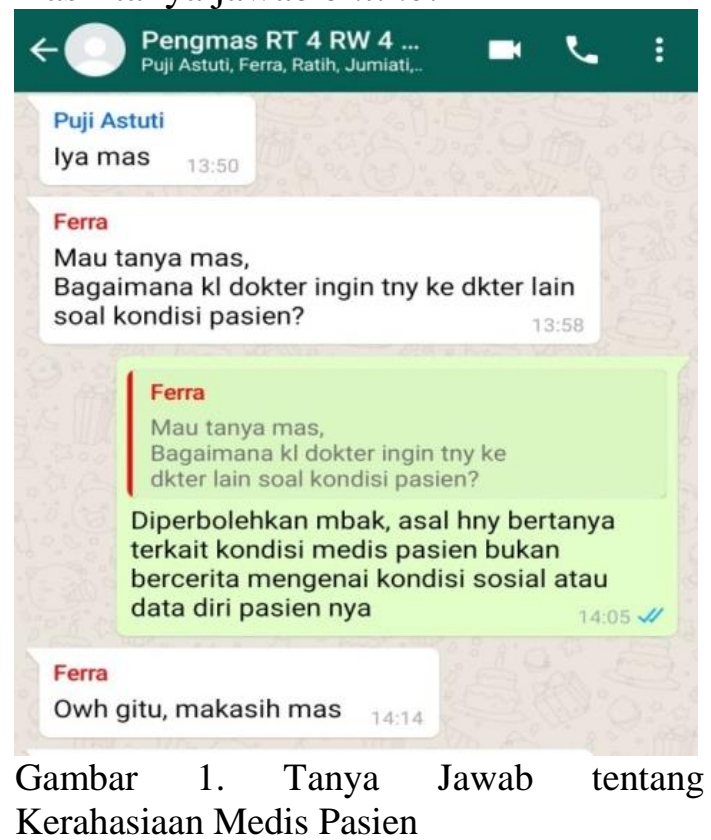




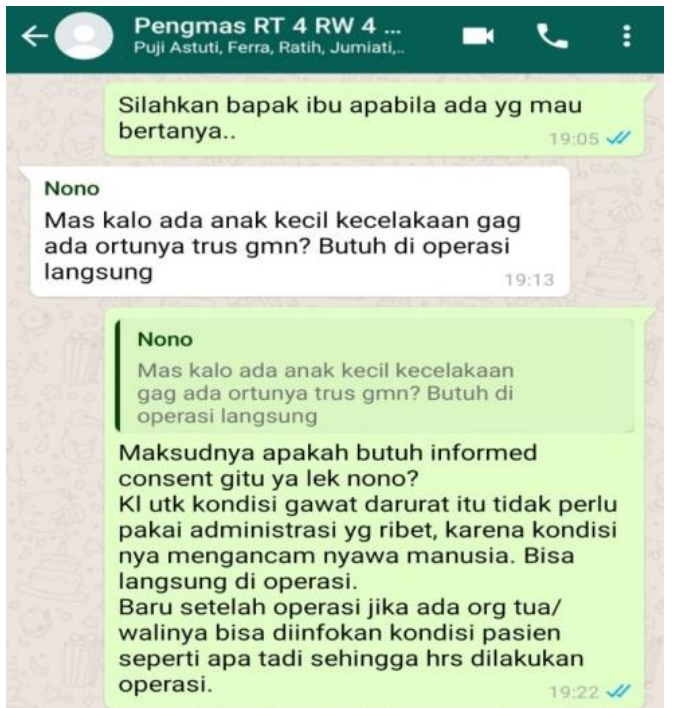

Gambar 2. Tanya Jawab tentang Prosedur Pelaksanaan Informed Consent

Distribusi Peserta berdasarkan pemahaman materi dapat dilihat pada tabel 3 berikut:

Tabel 3 Distribusi Frekuensi peserta PKM Berdasarkan Pemahaman materi

\begin{tabular}{cccc}
\hline No. & Pemahaman & Frek & Prosentase \\
\hline 1. & Baik & 16 & $61,5 \%$ \\
2. & Cukup & 6 & $23 \%$ \\
3 & Kurang & 4 & $15,5 \%$ \\
\hline \multicolumn{2}{c}{ Total } & 26 & $100 \%$ \\
\hline
\end{tabular}

\section{PEMBAHASAN}

Pada gambar 1, terdapat pertanyaan dari peserta yang mewakili tenaga kesehatan setempat yang bertanya terkait prosedur jika ada tenaga kesehatan atau dokter ingin berkonsultasi terkait kondisi pasien pada tenaga kesehatan lain. Dari pertanyaan peserta tersebut, dijawab oleh pemateri bahwa berbagi informasi pasien yang sedang ditangani tersebut hanya terbatas pada kondisi medis pasien saja tanpa menceritakan kondisi sosial pasien atau informasi lainnya, hal ini sudah sesuai dengan yang disampaikan pada (DPR RI, 2004).

Hal ini sesuai dengan pernyataan (Hatta, 2013) bahwa kerahasiaan medis adalah proteksi terhadap rekam medis dan informasi lain pasien dengan cara menjaga informasi pasien dan pelayanannya. Dalam pelayanan kesehatan, informasi itu hanya diperuntukkan bagi pihak tenaga kesehatan yang berwenang. Setiap dokter dalam melaksanakan praktik kedokteran wajib menyimpan kerahasiaan yang menyangkut riwayat pasien yang tertuang dalam rekam medis. Rahasia kedokteran tersebut dapat dibuka hanya untuk kepentingan pasien untuk memenuhi permintaan aparat penegak hukum, permintaan pasien sendiri atau berdasarkan ketentuan perundang-undangan yang berlaku (Depkes RI, 2013).

Pada gambar 2, terdapat pertanyaan dari peserta yang mewakili warga terkait penggunaan informed consent dalam kondisi gawat darurat pada pasien anak-anak. Dari pertanyaan peserta tersebut, dijawab oleh pemateri bahwa dalam penggunaan informed consent pada pasien anak-anak untuk 
persetujuan tindakannya diwakilkan oleh orang tua atau walinya, sedangkan dalam kasus gawat darurat penggunaan informed consent dapat diabaikan terlebih dahulu dan mendahulukan tindakan medis untuk menolong nyawa pasien, pernyataan ini sudah sesuai dengan yang disampaikan pada pasal 4 (Depkes RI, 2008b).

Informed consent merupakan hal mutlak diperlukan bagi pihak dokter sebelum ia melakukan tindakan medis bagi pasiennya yang diatur di dalam (DPR RI, 2009) Tentang Kesehatan Pasal 8, (DPR RI, 2004) Tentang Praktik Kedokteran Pasal 45 dan (Depkes RI, 2008a) Tentang Persetujuan Tindakan Kedokteran Pasal 2 ayat 1. Tindakan medis yang dilakukan oleh dokter tanpa adanya informed consent bagi pasien yang kondisinya gawat darurat dapat dilakukan, karena adanya pengecualian yang diatur pada penjelasan Pasal 45 dan Pasal 51 huruf d UU Praktik Kedokteran serta pasal 4 ayat 1 Permenkes. Semua itu didasarkan demi kesembuhan dan keselamatan pasien itu sendiri dan juga merupakan penerapan asas perlindungan dan keselamatan pasien yang dianut pada UU Kesehatan maupun UU Praktik Kedokteran. Persetujuan tindakan medis untuk pasien yang berada dalam unit gawat darurat berbeda dengan pasien secara umum, seorang pasien dalam kondisi darurat apabila sudah berada di dalam rumah sakit maka persetujuan tindakan medik dapat diabaikan.

Kegiatan pengabdian kepada masyarakat mengenai upaya menjamin kerahasiaan medis pasien di RT.4 RW.4 Kel. Jati Kec. Mayangan Kota Probolinggo secara daring ini telah berhasil dilaksanakan. Hasil evaluasi setelah dilaksanakannnya kegiatan pengabdian kepada masyarakat ini didapati masih adanya warga yang belum memahami pentingnya menjafa kerahasiaan medis tersebut sebanyak 15,5\%. Hal ini sangat wajar karena materi yang disampaikan adalah pengetahuan yang baru dan diperlukan ketekunan dalam memahami kerahasiaan medis tersebut. Namun, dalam implementasi upaya menjamin kerahasiaan medis pasien ini perlu adanya kepedulian dan perhatian dari para tenaga/kader kesehatan serta warga masyarakat sebagai pasien dalam hal pemahaman terkait hak dan kewajiban antara dokter/tenaga kesehatan dengan pasien sehingga dapat terciptanya rasa saling percaya terkait tugas dan fungsi masing-masing.

Oleh karena itu, perlu suatu inisiatif atau kesadaran dari para 
tenaga/kader kesehatan untuk bisa berkomunikasi aktif kepada pasien sehingga pasien dapat memahami hak dan kewajibannya dalam sebuah pelayanan medis melalui penggunaan persetujuan umum dan persetujuan tindakan medis sehingga tercapai derajat pelayanan fasilitas kesehatan yang baik dan berkualitas khususnya dalam menjamin kerahasiaan medis pasien.

\section{PENUTUP}

Pengabdian kepada masyarakat dengan judul "Edukasi Kesehatan Dalam Upaya Menjamin Kerahasiaan Medis Pasien Pada Fasilitas Pelayanan Kesehatan" yang dilakukan di RT.4 RW.4 Kel. Jati Kec. Mayangan Kota Probolinggo telah selesai dilaksanakan secara daring dengan pemberian materi secara online melalui grup whatsapp, tanya jawab virtual dan akses video pembelajaran. Hasil dari kegiatan yaitu peserta diantaranya tenaga/kader kesehatan dan warga masyarakat sudah mampu untuk mengerti mengenai pentingnya menjaga kerahasiaan medis pasien, hak dan kewajiban antara dokter dan pasien dan juga prosedur pelaksanaan privasi dan kerahasiaan medis yang benar.

\section{DAFTAR PUSTAKA}

Depkes RI. (2008). Peraturan Menteri Kesehatan Republik Indonesia Nomor:269/MEN.KES/PER/III/200 8 Tentang Rekam Medis.

Depkes RI. (2008). Peraturan Menteri Kesehatan No.290 tentang Persetujuan Tindakan Medis.

Depkes RI. (2013). Peraturan Menteri Kesehatan No. 55 Tahun 2013 tentang Penyelenggaraan Pekerjaan Perekam Medis.

DPR RI. (2004). Undang Undang No. 29 tentang Praktik Kedokteran.

DPR RI. (2009). Undang-Undang Dasar Negara Republik Indonesia No. 36 tahun 2009 tentang Kesehatan.

Hatta, G. (2013). Pedoman Manajemen Informasi Kesehatan di Sarana Pelayanan Kesehatan. Penerbit Universitas Indonesia.

Kemenkes RI. (2008). Peraturan Menteri Kesehatan No. 290 Tentang Persetujuan Tindakan Medis. Jakarta 